\title{
Coronavirus, Global Risk and The New International Crisis Management Model
}

\author{
Coronavirus, Risco Global e O Novo Modelo Internacional de Gestão de Crises \\ Coronavirus, Riesgo Global y El Nuevo Modelo Internacional de Gestión de Crisis \\ Jorge M. Lasmar ${ }^{1}$ \\ Leonardo Coelho Assunção Santa Rita²
}

DOI: $10.5752 / P .1809-6182.2020 v 17 n 3 p 47$

Received in June 26, 2020

Accepted in November 16, 2020

\begin{abstract}
The main target of this article is to discuss, in the light of the new crisis management models, the immediate responses that state authorities have given to the COVID-19 crisis, in order to better understand the way in which global leaders are facing the novel international crises.

Keywords: Coronavirus. Crisis Managent. Risk.

Resumo

O objetivo do artigo é discutir, à luz dos novos modelos de gestão de crise, as respostas imediatas que as autoridades estatais deram para a crise da COVID-19, a fim de entender melhor a maneira com que as lideranças globais estão enfrentando as novas crises internacionais.

Palavras Chave: Coronavirus. Gestão de Crise. Risco.

\section{Resumen}

El objetivo del artículo es discutir, a la luz de los nuevos modelos de gestión de crisis, las respuestas inmediatas que las autoridades estatales han dado a la crisis COVID-19, a fin de comprender mejor la forma en que los lideres mundiales se enfrentan a las nuevas crisis internacionales.

Palabras Clave: Coronavirus. Manejo de Crisis. Riesgo.
\end{abstract}

\footnotetext{
1 Jorge M. Lasmar is a Profesor of International Relations at PUC Minas, Belo Horizonte, Brazil. He holds a PhD in International Relations from the London School of Ecomomics and Political Science, LSE.

2 Leonardo Coelho Assunçáo Santa Rita is a master's student in the Postgraduate Program in International Relations at PUC Minas, Belo Horizonte, Brazil. He holds a Bachelor's degree in International Relations from the Pontifícia Universidade Católica de Minas Gerais, PUC Minas.
} 


\section{Coronavirus, Global Risk and The New International Crisis Management Model}

The first cases of the new Coronavirus (SARS-COV-2) contamination in humans arguably appeared on the outskirts of the Wuhan region, China, in late 2019. Even though the virus has a lower mortality rate when compared to other pathogens such as Ebola - which has an impressive fatality rate of 50\% (WHO, 2020a) - it does spread quickly. In fact, it is exactly such a spread rate that led a regional epidemic transform into a full-scale global Pandemic (WHO, 2020b). The pandemic, in its turn, brought about global-scale disruptions that go well beyond the issue of individual health: it impacted the very structure of societies. It affected global business and commerce (OECD, 2020), increased the mortality rates, affected the distribution of wealth, changed the priority and dynamics of the infrastructure matrix and even altered the behaviour of individuals and societies (GOOGLE, 2020).

In fact, both the global-scale crisis as well as the responses adopted to counter it were largely perceived as unprecedented. However, this is not the case. For at least a few years various 'global political risks estimates' have been pointing out the high risk of a global-scale pandemic disruption (WORLD ECONOMIC FORUM, 2019). Along the same lines, for almost a decade, there has also been a debate on the need to develop a new model of international crisis management capable of dealing with "novel" global-level disruption crises (OECD, 2013). Thus, to understand what the new model of international crisis management can teach us about present and future global crises, we will first outline a few important aspects of the
Coronavirus Pandemic (I), to then briefly describe the international responses (II) in order to better comprehend what is the new international crisis model and how it can help re-shape how we think about crisis managements (III) to finally conclude with the lessons learned from the current crisis.

\section{Key Features of the Coronavirus Crises: Context and Global Structure}

One of the defining characteristics of the new Coronavirus crisis is that it clearly follows globalisation. This is because there is a direct relationship between the contagion pathways and the intensity of transnational flows. If we follow both the maps and timeline of the virus contagion worldwide, there is a remarkable parallel between its ability to spread following from the first regions affected by the pandemic straight to the most heavily globalised locations (i.e. regions with denser global interactions flows) and then following to increasingly less globalised locations. After China and its neighbours, the Coronavirus spread more rapidly and more intensely throughout Western Europe and North America. By April 2020 these regions already led the international ranking in both number of cases and number of deaths (HEALTH MAP, 2020). Amongst other factors, what these regions have in common is that they also led the globalization index. This is an index which considers everything from economic to cultural and informational issues. Thus, we can infer that a positive correlation exists between the intensity of transnational flows and the spread of the virus (GYGLI et al, 2019).

In fact, this is not something new. Khanna (2020), for example, compares the spread of the new Coronavirus from China to the 
rest of the world with the spread of the Black Death in the 14 th century. The Black plague also followed the main pathway of transnational flows existing at that time: the silk road. The disease passed through Persia (now Iran) and reached Italy. However, the most interesting point about this analogy is not the similarity in the route of the virus. After all, in the case of COVID-19, the spread in Europe and North America occurred almost simultaneously. What comes to attention is the speed with which it spread (KHANA, 2020). In the 14th century, the Black Death took years to travel the Silk Road and affect Europe as a whole. In 2020, however, it took only a few months for the new Coronavirus to affect most of the world. Again, in both situations the intensity of transnational flows and globalization determined the pace of the international crisis.

This also seem to confirm Keohane's and Nye's statement that as the degree of interdependence amongst countries grows, so do the risks arising from the increase in their mutual level of sensitivity and vulnerability (KEOHANE, NYE, 2012). ${ }^{3}$ In other words, there is a tendency that the greater the density and intensity of flows, the higher the level of sensitivity and vulnerability will be. It is exactly this correlation between the greater density of sensitivity, risks and the pandemic effects of COVID-19 that will be discussed here. The increased density of interactions and flows also potentially increases risks. In fact, as the theory also points out, the risks and threats not only come from

3 According to Keohane and Nye (2012) "sensitivity refers to the costly effects of cross-border flows on societies and governments, within an unchanged framework of basic policies", while "vulnerability is another step further in cost. It refers to the costs of adjusting to the change indexed by sensitivity, by changing one's own policies" (KEOHANE, NYE, 2012, p. 232-233). traditional state sources (such as political-military threats) but can also have transnational and diffuse origins (KEOHANE, NYE, 2012). Nevertheless, this does not mean that the old state-generated risks are extinct or obsolete. What the pandemic does demonstrate is that the states face an environment of increased complexity. The traditional international risks co-exist with a host of non-traditional, transnational and diffuse threats that are growingly disruptive, more frequent and bringing up increasingly demanding challenges for the states.

Another striking key feature of the COVID-19 crisis is its disruptive power. Such power is reflected in the rapid cascade effect of the pandemic in other structural and social areas. Its impact ranges from global economic, logistic, and infrastructure disruptions to profound social, demographic, institutional and behavioural changes. The spread of the virus and the measures taken to contain it caused logistical difficulties to companies ranging from car factories to producers of digital games (STUART, 2020; DEBORD, 2020). Global economies have also been hit hard by the crisis. Since the start of the Pandemic, stock markets have experienced historic declines, while in the United States - the largest economy in the world - and elsewhere, millions of workers have signed up to receive unemployment insurance benefits (GLOBAL... 2020; RUSHE; HOLPUCH, 2020). In fact, we can safely state that the disruption brought about by the coronavirus crisis was strong enough to expose the many vulnerabilities of globalisation.

One final important element that characterizes the crisis of the new Coronavirus is the informational environment in which it is embedded. Never - not even during the H1N1 Pandemic in 2009 - has a crisis of this scope 
occurred in an environment in which information (and disinformation) flows so quickly and in such a decentralised manner. This has a double effect. On the one hand, it allows relevant information about the pandemic to quickly reach a significant number of people. On the other hand, it also allows disinformation to be disseminated at an even faster pace than the virus itself. This is a huge problem. A series of different actors employed disinformation during the outbreak to achieve different objectives. Fraudsters, pranksters, companies, states and political and social groups disseminated disinformation using varying methods and degrees of sophistication This wide spectrum of disinformation brought about both short-term and long-term risks and has actually proven to be potentially fatal (WATTS, 2020). In fact, the disinformation pandemic became so relevant that digital platforms such as YouTube, Facebook and Twitter have adopted - though they are still struggling - measures to inhibit and discourage the spread of false information that even included creating official channels of communication about the crisis (LING, 2020).

Thus, to peruse the state's responses to the new Coronavirus crisis can be an important tool to both evaluate the current state of our crisis management capabilities as well as to understand the challenges that lay ahead. This is so not only because the pandemic is a transnational crisis. We have faced other transnational crises before. The COVID-19 crisis is embedded within a new informational environment that was constructed globally after the spread of digital media. Additionally, the trophic cascade effects triggered by the global pandemic is another factor that make this crisis so unique and challenging for crisis managers. Finally, its unprecedented size, dimension and speed allow us to gauge how novel global crises will impact us in the future. Having this in mind, and learning from the current state's responses, can be an important tool to evaluate how to prepare for and manage new crises.

\section{States' Responses}

The COVID-19 pandemic crisis quickly became systemic. So did its disruptive effects. At first glance, to say that a pandemic and its disruptive effects became systemic might seem tautological, but that is most certainly not the case. To observe that the pandemic became systemic is to assert that not only its dynamics is determined by the autopoietic interaction between agent and structure (i.e., the fact that they are mutually constitutive), but also that its effects have produced a trophic cascade effect. In fact, the scale and seriousness of the matter led the Germany Chancellor, Angela Merkel, to declare that the current pandemic is the greatest challenge for her country since World War II (MERKEL... 2020). It is still relatively early for us to fully understand the real dimension of the crisis and compare it to a war is certainly debatable. However, when Germany compares the pandemic to World War II it does provide us with an idea of the scale of the public policies' responses that world leaders adopted. Likewise, the disruptive power of the pandemic is so high that former US Secretary of State Henry Kissinger said that the COVID-19 crisis will definitely change the global order (KISSINGER, 2020).

No one questions the scale of the state responses to contain the virus or the impacts those measures may have upon our daily lives. However, there is yet another hidden and more important underdiscussed impact: the pande- 
mic brought about a broader crisis of meaning. Whether one looks careful, several state and non-state responses seem to go in the opposite direction of what would be expected from the current crisis. We are witnessing the denial of science, the discrediting of international organizations, an increase in authoritarianism and a weakening of democracy, an informational and rhetorical war, an over-centralization and disorganization of the decision-making process, a return of hard borders and the poor coordination amongst states as well as between states and non-state actors. There are so many examples of these practices that is even difficult to list here. But take the denial of science, for example. Countries such Nicaragua, Belarus and Turkmenistan reject the very existence of Pandemic. These countries - together with a few others that do not deny the existence of the pandemic - reject the response protocols recommendations by the World Health Organisation and continue their everyday life as if nothing had changed in a clear example of discredit for international organisations (CORONAVIRUS... 2020a; PRESIDENT... 2020; RSF, 2020).

Thus, one of the important questions raised during the Pandemic is how it will affect democracies and whether some of them will withstand a systemic crisis of this magnitude. The crisis is creating both a material and social pressure to reframe how we confer meaning upon many international practices and values. Democracy is one such value. The common idea that there is a need for a strong state response to the pandemic has caused an upsurge in authoritarianism in some countries and the weakening of democracies in others, such as Hungary. On March 30, 2020, the Hungarian parliament approved a bill granting Prime Mi- nister Viktor Órban the power to govern by decree, that is, the ability to approve measures without the need to submit them to parliament. The justification of the Prime Minister and the parliamentarians who approved the decision is that the urgency imposed by pandemic requires that decisions be taken without much deliberation (DEMPSEY, 2020). This is a clear example of one out-of-many securitisation narratives within the pandemic, the question being whether the audience will accept it and for long. The real danger is that of 'normalisation of the extraordinary' (MOECKLI, 2008, p. 229), i.e. the general tendency for emergency regimes to become entrenched and engender definitive normative changes.

Another important reframing during the COVID-19 crisis is that of territoriality and borders. States responses to the pandemic undoubtedly led to a (re)strengthening of physical borders. Not only there was a deliberated closing of physical borders between countries to stop the spread of Coronavirus, but also several states turned away from solidarism, i.e., from cooperating in joint ventures in pursuit of common values (BUZAN, 2004, p. 62). This shift towards more pluralist relations can be clearly seen in those countries that engaged in a price war to secure medical supplies already destined to other countries (US... 2020). This shift can also be seen in the informational and narrative disputes over the Coronavirus engaged by the United States, Russia and China. The United States accuses China and Russia of both disinformation campaigns on social media and in blaming Washington as responsible for the Pandemic. Meanwhile, China accuses the USA of racism (AS... 2020; TRUMP... 2020). This war of narratives also reveals the very low level of coordination present among the great po- 
wers to manage a global crisis and also reflects an upsurge of rivalries between them. This is relevant because the common norms and goals of international society are created diffusely by the direct clash/negotiation of individual interests and by any 'performance and sanction' social control systems that exist in interstate society. Key actors exercise influence over weaker actors in interstate society mainly through processes of leadership, authority and coercion. Hence, changes in the behaviour of key actors have a greater potential to lead to shifts in shared norms and values in interstate society (LASMAR, 2012).

Finally, another relevant aspect of the states' responses is the notoriously poor coordination between state and non-state actors. An example is the lack of effective engagement to create industrial convergence and the production of items needed to fight the new Coronavirus. States and large industries, for example, are finding increasingly difficult to coordinate their efforts or are doing so via emergency state laws that eventually force the convergence (MULDER, 2020).

\section{The Old and the (not so) new crisis management model}

Dealing with a systemic crisis requires a complex risk management structure. This structure includes tools for risk identification and crisis preparedness, response teams and policies for crises management as well as mechanisms to evaluate the crisis afterwards (feedback and lessons learned). Thus, traditionally crisis management begins way before the crisis. Identifying threats and adequately preparing for them is essential to mitigate the potential consequences of a future crisis. In this sense, the first step to prepare to a large-scale disruptive crisis is to do a risk assessment (OECD, 2013). ISO defines risk assessment as "...that part of risk management which provides a structured process that identifies how objectives may be affected and analyses the risk in terms of consequences and their probabilities before deciding on whether further treatment is required" (ISO, p. 6, 2009). Thus, risk assessment is related to the general approach adopted by a government or organization to identify possible threats and risks.

Traditional risk assessment approaches are built using "sectoral analysis based on historical events" (OECD, 2013). This means that the entire crisis preparation and identification framework must first be divided into specific sectors (industrial, economic, sanitary, military, etc.) and be based on other historical events of the same type (OECD, 2013). In other words, to predict, identify and prepare for the COVID-19 crisis, states should have built preparedness structures dedicated exclusively to deal with a pandemic crisis based on the experience of past events such as the Influenza AH1N1 Pandemic. In fact, places such as Taiwan, Singapore and Hong Kong did so and were heralded for keeping their cases count low at the beginning of the pandemic (KUGUYO et al, 2020).

However, the COVID-19 pandemic is not a traditional crisis. The systemic cascading effect of the pandemic - which can be observed on the immediate social and economic consequences of the crisis - makes it inappropriate to adopt a sectorial and approach. Likewise, the new structural environment in which the crisis is embedded, makes it difficult to adopt measures based on past events. Crises of this nature require a different risk assessment approach to 
be able to deal more effectively with both uncertainty and complexity (OECD, 2013). In these cases, it is necessary to develop a national risk assessment designed with a broader view of risk. In other words, it is necessary to understand that there are multiple threats, a great number of unknowns and that any threat can trigger cascade effects in other areas. This broader view of risk assessment cannot be restricted to just one sector as it needs to hold a systemic view. Central governments must also coordinate with other stakeholders such as private companies and NGOs in identifying and anticipating threats. Therefore, cooperation between the central government and the various sectors of civil society is essential for the development of a national risk assessment (OECD, 2013).

Once the risk has been identified, the next step is to develop an action plan. This is especially important when the risk identified has either a high probability of occurrence or a significant consequence. The planning of traditional crisis emergencies is generally based on scenarios. In this technique, each agency and/ or government sector, develop a series of response protocols that must be adopted if a certain situation arises. Scenario-based planning depends directly on a fixed chain of command and predetermined procedures designed to deliver the right response at the right time (OECD, 2013). However, new crises, such as the new Coronavirus, no longer allow planning based on fixed scenarios and protocols. The uncertainty of contemporary crises and the fact that they are unprecedented, require approaches that are more flexible and capable of adapting better to the threat as it evolves. Planning for current crises requires building a response network whose focus is on capacity building rather than scenario planning. Multiple agen- cies must focus on coordinating their actions rather than preparing for specific threats. Leadership, innovation capacity and systems that allow cooperation are essential to prepare for new crises (OECD, 2013).

Once the main risks have been identified and adequately planned to address them, it is necessary to have trigger mechanisms that activate the response to the crisis. The traditional policy is the development of early warning systems that detect the occurrence of a threat and quickly initiate the response protocols. These systems are able to identify threats through intense monitoring and information sharing, such as natural disaster monitoring systems, for example. New crises however, due to their diffuse nature and the speed with which they arise, are often not detected by traditional means of early warning. These novel situations call for the development of strategic foresight capabilities in order to perceive and identify the weak signs present at the beginning of a crisis that often goes unnoticed. To develop such capabilities, it is necessary to set up a multidisciplinary intelligence network (OECD, 2013). This is clearly the case with the COVID-19 pandemic. States and organisations long ago already identified the high risk of pandemic-like crises. In the same lines, a significant number of government agencies, scientists and even CEOs of large companies already recognised the destructive potential that a highly contagious virus could cause and how unprepared we were (DAVIES, 2020). In fact, a study published in the journal Nature in 2015, a group of researchers warned precisely about the possibility of a new virus of the type "Coronavirus" escaping from bats and contaminating humans (MENACHERY, et al, 2015). Yet - although we do recognise the technical difficulties of early war- 
ning in biological threats - despite all the risk assessments and the various methods that countries and organisations had at their disposal to identify threats, there was no early warning.

This brings us back to an already mentioned interesting aspect of new crises. In addition to studies in the field of medicine and virology, some researchers in the field of social sciences have already identified the destructive potential of a global Pandemic. In his article on existential security submitted in September 2019, Nathan Sears (2020) pointed out that pandemics are one of the main "catastrophic" threats to humanity (SEARS, 2020). In the risk assessment document published by the American agency FEMA (Federal Emergency Management Agency) in 2019, the possibility of a global pandemic was identified as one of the main threats that the organization was preparing for (FEMA, 2019). More recently, a report published by $\mathrm{ABC}$ News revealed that the National Center for Medical Intelligence (NCMI) had already been reporting the possibility of a pandemic from China since November 2019. However, the Pentagon denied the claim and stated that the intelligence service began reporting the situation only in January 2020 (MARGOLIN; MEEK, 2020). Thus, if intelligence agencies and researchers were already aware of the risk of a global pandemic, what brought the COVID-19 crisis to the level it reached? Here comes an interesting aspect of the current scenario. The problem was not that of an intelligence failure, but rather that of a political botch. The failure laid not on the misidentification or wrong risk assessment. Instead, the failure was located on the initial response phase. Political rivalries, ideological extremism and lack of leadership negatively impacted the initial response phase and were among the main drivers of the crisis. Hence, this demons- trates the clear - more-than-ever - entanglement between politics and crisis management.

This entanglement aggravates yet another problem of the initial response to new crises. Traditionally, at the beginning of the crisis, those involved in its management construct what is termed the 'operational picture'. In traditional crises, the operational picture is designed through an accurate monitoring of the development of the crisis. In other words, the authorities identify the dimension of the problem, estimate its reach and impact, predict how it can evolve and plan the authorities' responsibilities in the response process (OECD, 2013). Nonetheless, because new crises are unprecedented or have discreet effects, they may not present a clear operational picture. Their threats and effects are diffuse, fast and unprecedented. The authorities, thus, need engage in a sense-making process to first understand what is actually happening and how big the problem is (OECD, 2015). The need for sense-making is clear in the COVID-19 crisis. Many authorities dealt with the pandemic in a state of complete dearth of information. As the crisis evolved, questions became more frequent and answers became scarcer and more imprecise. Even "simple" questions - such as: whether We should use protective masks (ROBERTS, 2020); What is the most appropriate method of social isolation? (KATZ, 2020), or; which drugs should be used against the virus (GOODMAN; GILES, 2020)? - became problematic. This reaffirms the importance of both engaging in fact-based sense-making as well as employing a multidisciplinary networked response combining civil society and governmental specialists to provide decision makers with the necessary tools to properly understand the crisis (OECD, 2018). 
It is important to note that there is some debate regarding a certain inability of scientists to communicate with the public. The use of elitist language combined with the almost exclusive use of the English in publications can create barriers between scientists, the population and the decision makers (LARIVIÈRE; SHU; SUGIMOTO, 2020). This is an important factor. A key point for science is that the results of academic research should be published and made available for scrutiny. The results should reach not only peer scientists but also the civil society as a whole. Thus, the communication of scientific research's results should aim at adopting the most simple and direct language as possible to effectively broadcast its finds to a broader audience without losing its scientific rigour. However, the fact that this is not always the case, is not an excuse. Unscientific practices and lack of coordination with specialists can seriously hamper the ability of sense-making. One striking example of how this can be so is the Turkmenistan president, Gurbanguly Berdymukhamedov, who came to condemn the use of the word 'Coronavirus' and recommended the use of the smoke of medicinal herbs to supposedly kill the virus (ABDURASULOV, 2020).

The same can be said about crisis management guidelines and protocols. In crisis management it is equally important to coordinate the response process and establish how it will be managed. To respond adequately to a crisis, governments usually construct certain operating standards (standard operating procedures or SOP) in advance. These pre-set standards have typically a hierarchical order in which units at a lower level directly depend on guidelines and instructions for units at a higher level. Nonetheless, the transnational, complex, diffuse and disruptive nature of modern crises requires a networked response. Managing a large response network requires sharing the responsibility with several stakeholders ranging from the central government, passing through sub-national units and international organisations and reaching the private sector. This responsibility network, although diverse, must be in constant communication and maintain a high level of coordination of its actions (OECD, 2013).

However, several of the international responses to the COVID-19 crisis went exactly on the opposite direction: they were centralised, inward-centric, and refused to cooperate with different stakeholders such as other states, international organisations and the civil society. Managing a large-scale response network has proven to be a major challenge for the authorities during the COVID-19 crisis. Examples of poor coordination amongst central governments, subnational entities, non-state actors and international organisations abound. Even within the context of the European Union, many countries have given unilateral responses to the crisis (JUST... 2020). In fact, this lack of coordination directly impacted the crisis in Italy, one of the most affected countries. According to Italian Prime Minister Giuseppe Conte, the EU project may fail if it is unable to respond adequately to the crisis (LOWEN, 2020).

It is also possible to identify a lack of coordination between the public and private sectors. For example, in early March 2020 the United States' main companies such as Google, Amazon and Apple were already implementing home office working while the government was questioning social isolation (ORACLE... 2020). Another example of poor coordination between government and the private sector was the attempt to make use of a wartime law to force industries to manufacture equipment 
to fight the pandemic (SIRIPURAPU, 2020). The lack of a cohesive cooperation between some important countries and the WHO is also striking. Perhaps, the most notable example is the U.S. decision to cut the WHO's funding on the grounds that the organisation is flawed and lenient with China (CORONAVIRUS... 2020b). Despite the fact that one can certainly question WHO's conduct during the crisis, reducing its funding during a global pandemic is not the best way to establish a response network amongst international stakeholders. Managing an international network depends heavily on cooperation between the major actors. Unfortunately, examples such as the altercations between United States and China were a common feature of this crisis (FEIGENBAUM, 2020).

These examples also point to another key factor in crisis management: leadership. Implementing an integrated and coordinated response network requires trust and resilience. Leadership is essential in this process as it is key to mobilise the different stakeholders and communicate with civil society (OECD, 2013). To manage the population's trust and expectations, leaders must constantly communicate with the public during the crisis. In traditional communication approaches, leaders usually update the status of the crisis, provide technical information and inform about the measures being adopted (OECD, 2013). Although this communication with civil society is still very important, such an approach is not enough to deal with crises set within the new information environment (OECD, 2013). In view of the characteristic uncertainties of the new crises, adjusting expectations and building trust is essential for good leadership. To be able to achieve this, the communication must not only inform about the state of affairs but must also transmit values to the audience and manage anxieties. The leadership, thus, have a key role in this process as it must convey sincerity, stability and competence in order to manage civil society's ever-changing expectations. This is a process called meaning-making (OECD, 2015). In order to establish a successful communication during crisis, leaders must make extensive use of new communication strategies, tools and vehicles. This is not only because social media has a broader reach but also because it is precisely in this environment that the greatest amount of misinformation is spread (OECD, 2015). Another related aspect enhanced by social media is the need for leaders to be accountable. Leaders have to respond adequately to the civil society's demands and expectations related to the crisis (OECD, 2015). The new communication tools allow the population to promote a more intense and detailed scrutiny of each measure adopted by the authorities. That is why leaders must be prepared to answer all questions however sensitive they may be. Leaders need to transmit to the audience the fundamental confidence and serenity needed in times of crisis (OECD, 2015).

In the COVID-19 crisis, international leaders made extensive use of the new media to establish dialogue with civil society. In fact, the use of social media has been the main means of communication used by some government officials for some time. However, during the crisis of the new Coronavirus, social networks have not been a platform for building meaning-making. The US Defence Department accused the Russian government of using tweets and blogs to falsely accuse the United States of being the creators and responsible for the new Coronavirus (BROAD, 2020; RANKIN, 2020). The European Union also made similar accu- 
sations. The Russian government denied accusing, instead, the USA of engaging in a fake news campaign (CORONAVIRUS... 2020c). This "blame-game" between great powers is very harmful and hardly an adequate communication strategy in times of crisis (OECD, 2015). Instead of using the internet to reassure and provide answers to the population, states engaged in a politically motivated "semantic war" (TRUMP... 2020; ROSENBERGER, 2020). Likewise, there are no apparent attempt to coordinate a joint international effort to manage the crisis of the new Coronavirus.

This leadership role was expected, in large part, from the United States. However, the American government displayed a lack of coordination even with its closest allies. Both Germany and France accused Washington of committing "modern piracy" by diverting shipments of protective masks that were heading towards these countries (CORONAVIRUS... 2020d; OKELLA, 2020). The European Union also failed to display leadership even within Europe as it was unable to coordinate actions amongst its own members. In fact, the European Commission President Ursula Von Der Leyen even apologised for not being able to assist Italy properly (HERSZENHOR, WHEATON, 2020; HENTLEY, 2020). Likewise, at the beginning of the pandemic, there was a high expectation that China would take up the role as the main international leader during the crisis filling up the Western leadership void. Nevertheless, China also failed to do so.

Finally, the new Coronavirus crisis revealed that accountability is a more sensitive issue than expected. Several states did not react well to the intense scrutiny that the new informational environment allowed and end up intensifying authoritarian measures. An interesting example beyond authoritarian regimes is that of Hungary. The country stands out as a young democracy, but it was shaken when the prime minister, Viktor Orbán, approved a bill granting power to govern without submitting decisions to the parliament with no set deadline. The measure was based on the argument that the urgency of the crisis requires faster political action (HOCKENOS, 2020). Actions such as this contribute negatively impact the trust-building between the government, its population and the international community.

Consequently, the scale of COVID-19 crisis, combined with the environment in which the crisis is embedded, has exposed states' deep inability to properly respond to novel international crisis. As it was described above, models and knowledge on how to manage novel crises are already known and have been long well diffused by relevant organisations such as the OECD. However, the pandemic demonstrate that most state authorities still think within the old crisis model. The rise of authoritarianism, the politicisation of science, the over-centralisation and over-specialisation of the crisis management process as well as the misuse of mass communication tools by the state during the new Coronavirus pandemic demonstrate that we still have a long way to go to effectively deal with the upcoming future global crises.

\section{Conclusion: Lessons Learned}

State responses to the crisis were by no means homogeneous. They were diverse encompassing a wild range of views on science, the role of international organisations, the civil society and about what measures should be adopted. However, as mentioned above, one common underlining aspect of most responses 
we have seen so far is that they reinforce old crisis management practices that do not seem to be the best response to the current crisis. The COVID-19 crises require a crisis management approach that takes into account the need of sense-making and meaning-building, the multiplicity of actors and channels of communication involved, the networked nature of its disruptive effects as well as the diffuse and unprecedented scale and nature of the crises. Thus, we should take this opportunity to understand that the COVID-19 crisis displays signs that this is not a once-upon-a-time crisis. It is imperative that we re-think the current crisis management models in order to better prepare and respond to increasingly diffuse, disruptive, sudden and unprecedented threats with a more adaptable and efficient system of crisis management.

In this process, it is important to learn from our mistakes. They can provide important lessons for the future. The first, and probably most important lesson is that contemporary crises call for new approaches. As much as similar events have occurred in the past - such as past pandemics - current global crises require a different strategy. This new approach is necessary because the structural environment in which the crises are embedded is fundamentally different from the past. It presents a series of new possibilities and limitations that were not available before. As an example, even though social media has been available for a while, it did not have the same reach and impact it has today. This can clearly be seen when comparing the role of social media during the $2009 \mathrm{H} 1 \mathrm{~N} 1$ and the 2020 New Coronavirus pandemics.

Another important lesson that can be learned from the COVID-19 crisis is the importance of cooperation and information sharing between different stakeholders. It is no longer possible to face today's crises by centralizing responses as the characteristics of the events and the environment in which they take place require joint, multilevel and multisectoral actions. It is essential that all different stakeholders coordinate their preparedness and responses in order to effectively build a more resilient society. The design of a network that shares common values, principles and approaches amongst its members successfully creating collective action becomes increasingly important. In this sense, it is also important that these shared principles and values are aligned with the scientific and technical specialised knowledge. As described above, sense-making and meaning-making are a crucial element in the management of unique crisis. Scientific and technical knowledge are fundamental to obtain situational awareness in diffuse and unprecedented crisis.

The COVID-19 Pandemic also raises question about the importance of effective leadership in times of crisis. The inability of several international leaders to communicate effectively combined with the constant "blame-game" - especially among the great powers - seriously hindered a joint international response. Of course, world leaders such as German Chancellor Angela Merkel and New Zeland's Prime Minister Jacinda Arden played a good role as communicators during the crisis. (RISING, MOULSON, 2020). However, as a whole, the pandemic clearly highlights the necessity for world leaders to improve their communication with the larger audience while, at the same time, also demonstrating that civil society also have a key role in improving the choices of the leaders in future crisis.

Several other measures to prevent the occurrence of new global pandemics on such a 
large scale have also been suggested. It is beyond the scope of this chapter to describe and discuss all of them. However, the calls for the reform of the World Health Organization stands out. Australia made one of the most prominent proposals for WHO reform. According to Australian Prime Minister Scott Morrison, WHO needs to be equipped with tools that guarantee more autonomy to the international organisation. In this manner, it could investigate in advance a potential health crisis or even propose containment strategies in lieu of state members. Additionally, Australia also proposed the creation of an independent auditing body that would oversee WHO's performance in a global crisis such as COVID-19 (FARR, 2020).

For all these reasons, it is essential to carry out a complete review of the procedures, strategies, techniques, tactics and tools employed during the COVID-19 crisis (OECD, 2020). The COVID-19 Pandemic underlined a fundamental element present in contemporary crises: the breach of confidence. Rebuilding civil society's trust in science, governments and international organisations is perhaps the most challenging element present in the twilight of the new Coronavirus crisis. The ability to rebuild trust and subsequently build resilience are the major challenges that we are confronted with in face the uncertainties of new crises (OECD, 2013).

\section{References}

ABDURASULOV, Abdujalil. Coronavirus: Why has Turkmenistan reported no cases?. BBC News. 2020. Available at: https://www.bbc.com/news/world-asia-52186521. Accessed: 11 May 2020.

AS Virus Spreads, China and Russia See Openings for Disinformation. The New York Times. 2020. Available at: https:// www.nytimes.com/2020/03/28/us/politics/china-russia-coronavirus-disinformation.html. Accessed: 18 April 2020.

BROAD, William J. Putin's Long War Against American Science. The New York Times. 2020. Available at: https:// www.nytimes.com/2020/04/13/science/putin-russia-disinformation-health-coronavirus.html. Accessed: 15 May 2020.

BUZAN, Barry. From International to World Society?: English School Theory and the Social Structure of Globalisation. Cambridge: Cambridge University Press, 2004.

CORONAVIRUS: Why are football teams in Belarus still playing?. BBC News. 2020a. Available at: https://www.bbc. com/news/av/world-europe-52221232/coronavirus-why-are-football-teams-in-belarus-still-playing. Accessed: 18 April 2020.

CORONAVIRUS: Russia denies spreading US conspiracy on social media. BBC News. 2020b. Available at: https://www. bbc.com/news/world-us-canada-51599009. Accessed: 15 May 2020 .

CORONAVIRUS: US accused of 'piracy' over mask 'confiscation'. BBC News. 2020c. Available at: https://www.bbc.com/ news/world-52161995. Accessed: 15 May 2020b.

CORONAVIRUS: US to halt funding to WHO, says Trump. BBC News. 2020d. Available at: https://www.bbc.com/news/ world-us-canada-52289056. Accessed: 14 May 2020.

DAVIES, Kevin. Blinking Red: 25 Missed Pandemic Warning Signs. Genetic Engineering and Biotechnology News. 2020. Available at: https://www.genengnews.com/a-lists/blinking-red-25-missed-pandemic-warning-signs/. Accessed: 7 May 2020.

DEBORD, Matthew. Ford and Toyota are shutting down plants in Asia and India, and BMW will idle its US factory during the coronavirus pandemic. Business Insider. 2020. Available at: https://www.businessinsider.com/coronavirus-ford-toyota-shutting-down-asia-india-plants-bmw-us-2020-3. Accessed: 13 April 2020.

DEMPSEY, Judy. Orbán Exploits Coronavirus Pandemic to Destroy Hungary's Democracy. Carnegie Europe. 2020.

FAAR, Malcolm. Australian PM pushes for WHO overhaul including power to send in investigators. The Guardian. 2020. Available at: https://www.theguardian.com/australia-news/2020/apr/22/australian-pm-pushes-for-who-overhaul-including-power-to-send-in-investigators. Accessed: 18 May 2020.

FEINGENBAUM, Evan A. U.S.-China Coordination Missing in Action on Coronavirus. Carnegie Endowment for International Peace. 2020. Available at: https://carnegieendowment.org/2020/04/01/u.s.-china-coordination-missing-in-action-on-coronavirus-pub-81432. Accessed: 15 May 2020.

FEMA. 2019 National Threat and Hazard Identification and Risk Assessment (THIRA): Overview and Methodology. Federal Emergency Management Agency. 2019.

GLOBAL stocks fall again despite virus rescue efforts. BBC News. 2020. Available at: https://www.bbc.com/news/business-52000309. Accessed: 14 April 2020. 
GOODMAN, Jack; GILES, Christopher. Coronavirus and hydroxychloroquine: What do we know? BBC News. 2020. Available at: https://www.bbc.com/news/51980731. Accessed: 10 May 2020.

GOOGLE. Coronavirus: O Mundo Nunca Mais Será o Mesmo. S.D. S.L. Google. 2020.

GYGLI, Savina et al. The KOF Globalisation Index - revisited. Review of International Organizations, vol. 14, n. 3, p. 543574, 2019. Available at: https://doi.org/10.1007/s11558-01909344-2. Accessed: 12 April 2020.

HEALTH MAP. Health Map: COVID-19. Health Map Organization. 2020. Available at: https://www.healthmap.org/ covid-19/. Accessed: 12 April 2020.

HENTLEY, Jon. EU offers 'heartfelt apology' to Italy over coronavirus response. The Guardian. 2020. Available at: https:// www.theguardian.com/world/2020/apr/16/eu-offers-heartfelt-apology-italy-coronavirus-response-herd-immunity. Accessed: 17 May 2020.

HERSZENHORN, David M; WHEATON, Sarah. How Europe failed the coronavirus test: Contagion's spread is a story of complacency, overconfidence and lack of preparation. Politico. 2020. Available at: https://www.politico.eu/article/coronavirus-europe-failed-the-test/. Accessed: 16 May 2020.

HOCKENOS, Paul. Coronavirus and the Dawn of Post-Democratic Europe. Foreign Policy. 2020. Available at: https:// foreignpolicy.com/2020/03/31/hungary-orban-coronavirus-europe-democracy/. Accessed: 17 May 2020.

ISO. International standard ISO/IEC 31010, Risk management — Risk assessment techniques. 2009.

JUST when Italy really needed some unity, the EU failed it - and continues to do so. The Guardian. 2020. Available at: https://www.theguardian.com/world/2020/apr/19/european-union-italy-unity-failure-debt-germany-netherlands. Accessed: 11 May 2020.

KATZ, David L. Is Our Fight Against Coronavirus Worse Than the Disease? The New York Times. 2020. Available at: https:/www.nytimes.com/2020/03/20/opinion/coronavirus-pandemic-social-distancing.html. Accessed: 10 May 2020.

KEOHANE, Robert O. NYE, Joseph S. Power and Interdependence. Boston: Longman Classics in Political Science, 2012.

KHANA, Parag. Covid-19 Is Traveling Along the New Silk Road. Wired. 2020. Available at: https://www.wired.com/ story/covid-19-is-traveling-along-the-new-silk-road. Accessed: 13 April 2020.

KISSINGER, Henry A. The Coronavirus Pandemic Will Forever Alter the World Order. Wall Street Journal: Opinion. 2020. Available at: https://www.wsj.com/articles/ the-coronavirus-pandemic-will-forever-alter-the-world-order-11585953005. Accessed: 16 April 2020.

KUGUYO, Oppah; KENGNE, Andre Pascal; DANDARA,
Collet. Singapore COVID-19 Pandemic Response as a Successful Model Framework for Low-Resource Health Care Settings in Africa? Journal of Integrative Biology 24(8), 2020.

LARIVIÈRE, Vincent; SHU, Fei; SUGIMOTO, Cassidy. The Coronavirus (COVID-19) outbreak highlights serious deficiencies in scholarly communication. LSE Impact Blog. 2020. Available at: https://blogs.lse.ac.uk/impactofsocialsciences/2020/03/05/the-coronavirus-covid-19-outbreak-highlights-serious-deficiencies-in-scholarly-communication/. Accessed: 11 May 2020.

LASMAR, Jorge M. Managing great powers in the post-Cold War world: old rules new game? The case of the global war on terror. Cambridge Review of International Affairs, 28(3), 2012.

LING, Justin. An Epidemic of Wuhan Virus Misinformation Is Spreading Online. Foreign Policy. 2020. Available at: https://foreignpolicy.com/2020/02/05/coronavirus-epidemic-wuhan-misinformation-online-social-medial. Accessed: 15 April 2020.

LOWEN, Mark. Coronavirus: EU could fail over outbreak, warns Italy's Giuseppe Conte. BBC News. 2020. Available at: https://www.bbc.com/news/world-europe-52224838. Accessed: 12 May 2020.

MACHENARY, Vineet D et al. A SARS-like cluster of circulating bat coronaviruses shows potential for human emergence. Natural Medicine, Vol. 21, p. (1508 - 1513), 2015.

MARGOLIN, Josh; MEEK, James Gordon. Intelligence report warned of coronavirus crisis as early as November: Sources. ABC News. 2020. Available at: https://abcnews.go.com/ Politics/intelligence-report-warned-coronavirus-crisis-early-november-sources/story?id=70031273. Accessed: 9 April 2020.

MERKEL: Coronavirus is Germany's greatest challenge since World War II. Deutsche Welle. 2020. Available at: https:// www.dw.com/en/merkel-coronavirus-is-germanys-greatest-challenge-since-world-war-ii/a-52830797. Accessed: April $15,2020$.

MOECKLI, D. Human Rights and Non-discrimination in the 'War on Terror'. Oxford: Oxford University Press, 2008.

MULDER, Nicholas. The Coronavirus War Economy Will Change the World. Foreign Policy. 2020. Available at: $\underline{\text { ht- }}$ tps://foreignpolicy.com/2020/03/26/the-coronavirus-war-economy-will-change-the-world/. Accessed: 19 April 2020.

ORACLE, Apple, Google, and Amazon are among the largest global companies who have restricted travel or asked their employees to work remotely as a precaution against the novel coronavirus. Here's the full list. Business Insider. 2020. Available at: https://www.businessinsider.com/companies-asking-employees-to-work-from-home-due-to-coronavirus-2020. Accessed: 14 May 2020.

OECD. Coronavirus: The World Economy at Risk. Paris: 
OECD Interim Economic Outlook. Organization of Economic Cooperation and Development. 2020.

OECD. OECD Risk Management: STRATEGIC CRISIS MANAGEMENT. Organization of Economic Cooperation and Development. 2013.

OECD. Scientific Advice During Crises: Facilitating Transnational Co-operation and Exchange of Information. OECD Publishing, Paris. 2018.

OECD. The Changing Face of Strategic Crisis Management. OECD Reviews of Risk Management Policies, OECD Publishing, Paris. 2015.

OKELLA, Christina. Face masks from China intended for France 'hijacked' by US at the last minute. RFI. 2020. Available at: http://www.rfi.fr/en/europe/20200402-china-coronavirus-face-mask-france-stolen-us. Accessed: 16 May 2020.

PRESIDENT nowhere to be seen as Nicaragua shuns coronavirus curbs. The Guardian. 2020. Available at: https://www. theguardian.com/world/2020/apr/08/nicaragua-daniel-ortega-missing-anger-fear-month. Accessed: 17 April 2020.

RANKIN, Jennifer. Russian media 'spreading Covid-19 disinformation'. The Guardian. 2020. Available at: https://www. theguardian.com/world $/ 2020 / \mathrm{mar} / 18 /$ russian-media-spreading-covid-19-disinformation. Accessed: 15 May 2020.

RISING, David; MOULSON, Geir. Coronavirus: Germany's Angela Merkel wins public support in virus crisis as power in leadership role wanes. Independent. 2020. Available at: https:// www.independent.co.uk/news/world/europe/coronavirus-germany-chancellor-angela-merkel-cases-deaths-a $9432346 . h \mathrm{hml}$. Accessed: 17 May 2020.

ROBERTS, Michelle. Coronavirus: Who should wear a face mask or face covering? BBC News. 2020. Available at: https:// www.bbc.com/news/health-51205344?utm source=socialmedia\&utm medium=posts facebook. Accessed: 10 June 2020.

ROSENBERGER, Laura. China's Coronavirus Information Offensive: Beijing Is Using New Methods to Spin the Pandemic to Its Advantage. Foreign Affairs. 2020. Available at: https://www.foreignaffairs.com/articles/china/2020-04-22/ chinas-coronavirus-information-offensive? utm source=twitter posts\&utm medium=social\&utm campaign=tw daily soc. Accessed: 16 May 2020;

RSF. Coronavirus off limits in Turkmenistan. Reporters Without Borders. 2020. Available at: https://rsf.org/en/news/ coronavirus-limits-turkmenistan. Accessed:18 April 2020.

RUSHE, Dominic. HOLPUCH, Amanda. Record $3.3 \mathrm{~m}$ Americans file for unemployment as the US tries to contain Covid-19. The Guardian. 2020. Available at: https:// www.theguardian.com/business/2020/mar/26/us-unemployment-rate-coronavirus-business. Accessed: 14 April 2020.

SEARS, Nathan Alexander. Existential Security: Towards a Security Framework for the Survival of Humanity. Global Policy, vol. 11, n. 2, p. (255 - 266), April 2020.

SIRIPURAPU, Anshu. What Is the Defense Production Act? Council on Foreign Relations. 2020. Available at: $\quad$ https://www.cfr.org/in-brief/what-defense-production-act? $u$ tm content $=042520 \& u$ utm source $=$ tw \&utm medium=social owned. Accessed: 13 May 2020.

STUART, Keith. The Last of Us Part II delayed by coronavirus - is this the start of a trend?. The Guardian. 2020. Available at: https://www.theguardian.com/games/2020/apr/03/thelast-of-us-part-ii-delayed-playstation-sony. Accessed: 13 April 2020.

TRUMP defends calling coronavirus the 'Chinese virus'. Al-Jazeera. 2020. Available at: https://www.aljazeera.com/programmes/newsfeed/2020/03/trump-defends-calling-coronavirus-chinese-virus-200323102618665.html. Accessed: 16 May 2020.

TRUMP angers Beijing with 'Chinese virus' tweet. BBC News. 2020. Available at: https://www.bbc.com/news/world-asia-india-51928011. Accessed: 18 April 2020.

US hijacking mask shipments in rush for coronavirus protection. The Guardian. 2020. Available at: https://www.theguardian.com/world/2020/apr/02/global-battle-coronavirus-equipment-masks-tests. Accessed: 18 April 2020.

WATTS, Clint. The Disinformation Outbreak About the Coronavirus Outbreak: What to Make of the False Information Plague? Foreign Policy Research Institute. 2020.

WHO. Ebola virus disease. World Health Organization. 2020a. Available at: https://www.who.int/health-topics/ebo-

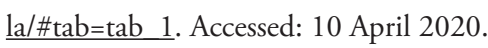

WHO. WHO Coronavirus Disease (COVID-19) Dashboard. World Health Organization. 2020b. Available at: https://covid19.who.int/. Accessed: 10 April 2020.

WORLD ECONOMIC FORUM. The Global Risks Report 2019 14th Edition. World Economic Forum. 2019. 